\title{
Effects of Fluid Distribution on Measured Geophysical Properties for Partially Saturated, Shallow Subsurface Conditions
}

P.A. Berge, B.P. Bonner, J.J. Roberts, D. Wildenschild, C.M. Aracne Ruddle, J.G. Berryman, H. Bertete-Aguirre, C.O. Boro and E.D. Carlberg

August 3, 2000

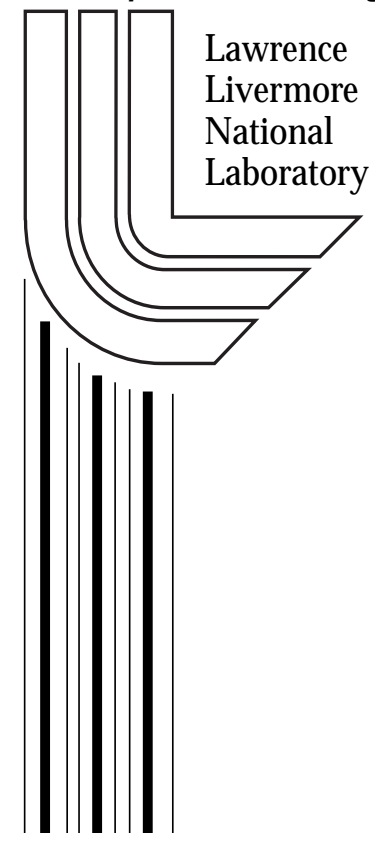




\section{DISCLAIMER}

This document was prepared as an account of work sponsored by an agency of the United States Government. Neither the United States Government nor the University of California nor any of their employees, makes any warranty, express or implied, or assumes any legal liability or responsibility for the accuracy, completeness, or usefulness of any information, apparatus, product, or process disclosed, or represents that its use would not infringe privately owned rights. Reference herein to any specific commercial product, process, or service by trade name, trademark, manufacturer, or otherwise, does not necessarily constitute or imply its endorsement, recommendation, or favoring by the United States Government or the University of California. The views and opinions of authors expressed herein do not necessarily state or reflect those of the United States Government or the University of California, and shall not be used for advertising or product endorsement purposes.

Work performed under the auspices of the U. S. Department of Energy by the University of California Lawrence Livermore National Laboratory under Contract W-7405-Eng-48.

This report has been reproduced directly from the best available copy.

Available to DOE and DOE contractors from the

Office of Scientific and Technical Information

P.O. Box 62, Oak Ridge, TN 37831

Prices available from (423) 576-8401

http://apollo.osti.gov/bridge/

Available to the public from the National Technical Information Service

U.S. Department of Commerce 5285 Port Royal Rd., Springfield, VA 22161 http://www.ntis.gov/

OR

Lawrence Livermore National Laboratory Technical Information Department's Digital Library http://www.llnl.gov/tid/Library.html 
FY2000 Annual Report for EMSP Project \#70108

\section{Effects of Fluid Distribution on Measured Geophysical Properties for Partially Saturated, Shallow Subsurface Conditions}

Aug. 3, 2000

Lead Principal Investigator:

Patricia A. Berge (LLNL, PO Box 808, MS L-201, Livermore, CA 94550; 925-423-4829; berge1@1lnl.gov)

Co-Investigators:

Brian P. Bonner (LLNL, PO Box 808, MS L-201, Livermore, CA 94550; 925-422-7080; bonner1@1lnl.gov)

Jeffery J. Roberts (LLNL, PO Box 808, MS L-201, Livermore, CA 94550; 925-422-7108; roberts17@1lnl.gov)

Dorthe Wildenschild (LLNL, PO Box 808, MS L-202, Livermore, CA 94550; 925-422-0257; wildenschild1@1lnl.gov)

Contributors (LLNL):

Chantel M. Aracne Ruddle, James G. Berryman, Hugo Bertete-Aguirre, Carl O. Boro, Eric D. Carlberg

Research Objective

Our goal is to improve geophysical imaging of the vadose zone. We will achieve this goal by providing new methods to improve interpretation of field data. The purpose of this EMSP project is to develop relationships between laboratory measured geophysical properties and porosity, saturation, and fluid distribution, for partially saturated soils. Algorithms for relationships between soil composition, saturation, and geophysical measurements will provide new methods to interpret geophysical field data collected in the vadose zone at sites such as Hanford, WA.

Research Progress and Implications

This report summarizes work after 10 months of a 3-year project. We have modified a laboratory ultrasonics apparatus developed in a previous EMSP project (\#55411) so that we can make velocity measurements for partially-saturated samples rather than fully-saturated or dry samples. We are testing the measurement apparatus using standard laboratory sand samples such as Ottawa sand samples. Preliminary results indicate that we can measure both compressional and shear velocities in these sand samples. We have received Hanford soil samples (sands from split-spoon cores from an uncontaminated site) and expect to make ultrasonic measurements on them also. We have used the LLNL x-ray facility to perform x-ray computed tomography (XCT) imaging for several partially-saturated Ottawa sand and Lincoln sand samples, and have also used the DOE Advance Photon Source at Argonne National Laboratory to make higher-resolution images of some sand samples. Preliminary results indicate that we can image amount and distribution of fluids in homogeneous sand samples. Continuing work from the previous EMSP project, we are testing a new data analysis method for seismic data that is expected to improve interpretation of 
seismic data from the vadose zone by showing how partial saturation affects seismic parameters. Our results suggest that the planned approach for this research is appropriate, that microstructure is an important factor for measured geophysical properties, and that seismic field experiments should be designed to collect both compressional and shear wave velocity data. We are also continuing to develop algorithms for relating geophysical properties to soil composition and hydrological parameters. The lead P.I. attended the EMSP Principal Investigator Orientation Meeting held in Richland, WA, in November, 1999, and presented preliminary results at the Advanced Vadose Zone Characterization Workshop that was held in Richland, WA, in January, 2000, as well as the EMSP National Workshop held in Atlanta, GA in April, 2000. Results have also been presented at scientific meetings and in journal papers as listed below.

\section{Planned Activities}

We plan to continue making laboratory measurements of compressional and shear velocities for partially saturated soils at low pressures, in the first two years of this project. We will also continue to make XCT images of partially saturated samples during the first two years of this project. In the second year, we will focus on using rock physics theories and laboratory measurements to relate measured velocities to saturation and composition for soils. This work also will make use of results from a previous EMSP project (\#55411) and other available geophysical data. In the second and third years of the project, we will focus on developing algorithms for relationships between composition, saturation, and geophysical measurements.

We are also networking with other current and former EMSP project P.I.'s (e.g., C. Carrigan, LLNL, E. Majer, LBL, D. Steeples, U. Kansas, R.J. Knight, Stanford/U. British Columbia) to plan possible future collaborations on field experiments to test the lab and theory results of this EMSP project, since this EMSP project is developing methods for improving interpretation of field experiment data used for subsurface imaging. The P.I. for this project provided advice about geophysical field experiment design for subsurface imaging at the Hanford site, at the Advanced Vadose Zone Characterization Workshop and in follow-up discussions.

This project and the previous project for which it is a continuation (\#55411) produced two patent applications (listed below).

Information Access

Copies of many of these documents may be viewed online or downloaded at the URL http://www.llnl.gov/tid/lof/

by performing a search using the UCRL number of the document or the author name.

Aracne-Ruddle, C. M., Bonner, B. P., Trombino, C. N., Hardy, E. D., Berge, P. A., Boro, C. O., Wildenschild, D., Rowe, C. D., and Hart, D. J., 1999, Ultrasonic velocities in unconsolidated sand/clay mixtures at low pressures (abstract): LLNL report UCRL-JC-135621-ABS, Eos, Transactions of the American Geophysical Union, 80, Fall Meeting Supplement, F397.

Aracne-Ruddle, C. M., Bonner, B. P., Trombino, C. N., Hardy, E. D., Berge, P. A., Boro, C. O., Wildenschild, D., Rowe, C. D., and Hart, D. J., 1999, Ultrasonic velocities in unconsolidated sand/clay mixtures at low pressures: LLNL report UCRL-JC-135621. 
Berge, P. A., 2000, EMSP Project 70108: Effects of Fluid Distribution on Measured Geophysical Properties for Partially Saturated, Shallow Subsurface Conditions: LLNL report UCRL-JC-

137130-ABS rev. 1, Science Advancing Solutions EMSP National Workshop Guidebook for the Environmental Management Science Program (EMSP) National Workshop, sponsored by the DOE EMSP, April 25-27, 2000, Atlanta, Georgia. (Also PowerPoint presentation UCRL-VG137130 and electronic poster UCRL-MI-137130.)

Berge, P. A., 2000, Powerpoint Presentation on EMSP Project 70108: Effects of Fluid Distribution on Measured Geophysical Properties for Partially Saturated, Shallow Subsurface Conditions: LLNL report UCRL-VG-137423, presented at the EMSP Principal Investigator Orientation Meeting, sponsored by EMSP and PNNL, held Nov. 16-18, 1999, in Richland, WA.

Berge, P. A., 2000, Powerpoint Presentation on Effects of Fluid Distribution on Measured Geophysical Properties for Partially Saturated, Shallow Subsurface Conditions: LLNL report UCRL-VG-137423 rev. 1, presented at the Advanced Vadose Zone Characterization Workshop, sponsored by the PNNL Hanford Groundwater/Vadose Zone Integration Project, held Jan. 19-20, 2000, in Richland, WA.

Berge, P. A., and Bertete-Aguirre, H., 2000, Laboratory velocity measurements used for inferring soil distributions from field seismic data: LLNL report UCRL-JC-135132, in Powers, M. H., Ibrahim, A.-B., and Cramer, L., Eds., Proceedings of the 13th Annual Symposium on the Application of Geophysics to Engineering and Environmental Problems (SAGEEP), Arlington, Virginia, February 20-24, 2000, Environmental and Engineering Geophysical Society, Wheat Ridge, CO, 185-194.

Berryman, J. G., 1999, Robust discrimination of porosity and fluid saturation using seismic velocity analysis, LLNL Patent disclosure IL-10437, December 8, 1998, and patent application, DOE Patent Docket No. S-92015, October 4, 1999.

Berryman, J. G., Berge, P. A., and Bonner, B. P., 1999, Role of $\lambda$-diagrams in estimating porosity and saturation from seismic velocities (expanded abstract): LLNL report UCRL-JC134224, 4 p., Society of Exploration Geophysicists International Exposition and 69th Annual Meeting Technical Program, held in Houston, Texas, October 31-November 5, 1999, Vol. I, 176179.

Berryman, J. G., Berge, P. A., and Bonner, B. P., 2000, Estimating rock porosity and fluid saturation using only seismic velocities: LLNL report UCRL-JC-135507, submitted to Geophysics.

Berryman, J. G., Berge, P. A., and Bonner, B. P., 2000, Transformation of seismic velocity data to extract porosity and saturation values for rocks: LLNL report UCRL-JC-136703, Journal of the Acoustical Society of America, 107, 1-10.

Bertete-Aguirre, H., and Berge, P. A., 1999, Laboratory ultrasonic measurements of sand-clay mixtures used to recover clay content in silty sands (abstract): LLNL report UCRL-JC-135643ABS, Eos, Transactions of the American Geophysical Union, 80, Fall Meeting Supplement, F395-396. 
Bonner, B. P., Boro, C., and Hart, D. J., 1999, Anti-waveguide for ultrasonic testing of granular media under elevated stress, LLNL Patent disclosure IL-10607, and patent application, DOE Patent Docket No. S-94182, October 28, 1999.

Bonner, B. P., Berge, P. A., Aracne-Ruddle, C. M., Bertete-Aguirre, H., Wildenschild, D., Trombino, C. N., and Hardy, E. D., 2000, Linear and nonlinear ultrasonic properties of granular soils: LLNL report UCRL-JC-136207, presented at the Materials Research Society Spring Meeting, April 24-28, 2000, San Francisco, CA. Also in Sen, S., Hunt, M., and van Swol, F., Eds., The Granular State, Symposium BB, Materials Research Society, Warrendale, Pa, in press.

Wildenschild, D., J.J. Roberts and E. D. Carlberg, 1999, Electrical properties of sand-clay mixtures: The effect of microstructure (expanded abstract): LLNL report UCRL-JC-135208, Society of Exploration Geophysicists International Exposition and 69th Annual Meeting Technical Program, held in Houston, Texas, October 31-November 5, 1999, Vol. I, 461-464.

Wildenschild, D., J.J. Roberts and E. D. Carlberg, 2000, On the relationship between microstructure and electrical and hydraulic properties of sand-clay mixtures: LLNL report UCRLID-136122, Geophysical Research Letters, in press.

This work was performed under the auspices of the U. S. Department of Energy by University of California Lawrence Livermore National Laboratory under contract No. W-7405-ENG-48. 